\title{
A MARCA DA VIOLÊNCIA NAS RELAÇÕES DE EMPREGO: PRECARIZAÇÃO E DESREGULAMENTAÇÃO DOS DIREITOS TRABALHISTA NO SETOR PÚBLICO BRASILEIRO
}

THE BRAND OF VIOLENCE IN EMPLOYMENT RELATIONS: PRECARIZATION AND IMPROVEMENT OF LABOR RIGHTS IN THE BRAZILIAN PUBLIC SECTOR

Francisco Ercilio Mouraa, Francysco Pablo Feitosa Gonçalves ${ }^{a}$

UNILEÃOa

E-mail: ercilio@leaosampaio.edu.br

\section{RESUMO}

Ao reflexionar sobre as violentas formas e magnitudes que caracterizam as desiguais relações trabalhistas no sector público brasileiro, cujo paradigma traz a marca das práticas da intermediação, dando lugar a processos sociais, políticos e institucionais que longe de dotar o serviço público de estandáres eficientes em seu ciclo produtivo, aprofundam as desiguais relações laborais na administração pública em suas multiplas dimensões federal, estadual e municipal. Deste modo, propomos uma reflexão crítica acerca do contexto socioeconômico e político em que se dá a flexibilização das relações de trabalho no Brasil, com ênfase na nossa Administração Pública, identificando os principais dispositivos do ordenamento jurídico brasileiro que legitimam a terceirização, definida como relação trilateral formada entre trabalhador, intermediador e o tomador de serviços, caracterizada pela não individualização do empregador real dentro do campo da relação de trabalho formal.

Palavras-chave: Administração Pública; intermediação; relações terceirizadas; triangulações laborais.

\section{ABSTRACT}

Reflecting on the violent forms and magnitude that characterize the unequal labor relations in the Brazilian public sector, whose paradigm bears the mark of intermediation practices, giving way to social, political and institutional processes that far from providing the public service with efficient standards in their productive cycle, deepen the unequal labor relations in the public administration in its multiple federal, state and municipal dimensions. Thus, we propose a critical reflection on the socioeconomic and political context in which labor relations are made more flexible in Brazil, with emphasis on our Public Administration, identifying the main provisions of the Brazilian legal system that legitimize outsourcing, defined as a trilateral relationship. formed between worker, intermediary and service taker, characterized by the non-individualization of the real employer within the field of formal employment relationship.

Keyword: Public Administration; intermediation; outsourced relationships; labor triangulations 


\section{CONSIDERAÇÕES INICIAIS}

Os sistemas simbólicos (e.g. a língua, a religião, a arte, a ciência etc.) configuram a forma como percebemos, compreendemos e agimos no mundo (BOURDIEU, 1989, p. 9). O presente trabalho aborda assuntos e conceitos que às vezes podem ser bastante sensíveis. Em tempos de ignorância e infantilismo político, quando apontamos algum problema do capitalismo e do neoliberalismo, por exemplo, existe a possibilidade de o interlocutor, dependendo de seu fetichismo político-ideológico, simplesmente se fechar ao que está sendo dito; por outro lado, quando criticamos os aspectos perniciosos da Administração Pública, também é possível que o interlocutor, orientado por interesses corporativistas, se torne incapaz de compreender o que foi dito. Precisamos nos policiar, portanto, para que diante de uma exposição de como as coisas são, nossas paixões políticas e intelectuais não distorçam a nossa visão da realidade: o capitalismo tem problemas, a Administração Pública tem problemas, toda invenção humana pode ter problemas, e quando nos recusamos a enfrentá-los, estamos sendo coniventes e contribuindo para a sua continuidade.

$\mathrm{O}$ presente artigo, cuja finalidade consiste em reflexionar sobre as violentas formas de mediações que caracterizam as desiguais relações laborais na administração pública brasileira, violência que na seara das relações laborais encontra seu clímax no fenômeno da terceirização como forma de contratação da força de trabalho no âmbito da Administração Pública e seus impactos desagregadores das relações de trabalho e dos direitos trabalhistas que lhe são inerentes.

Desse modo, com base em pesquisa bibliográfica e documental, incluindo consulta a livros, artigos e legislação pertinentes ao tema, iniciamos uma reflexão crítica acerca do contexto socioeconômico e político em que se dá a flexibilização das relações de trabalho no Brasil, com ênfase na nossa Administração Pública, identificando os principais dispositivos do ordenamento jurídico brasileiro que legitimam a terceirização, definida como relação trilateral formada entre trabalhador, intermediador e o tomador de serviços, caracterizada pela não individualização do empregador real dentro do campo da relação de trabalho formal.

\section{DO QUE ESTAMOS FALANDO MESMO? ESTABELECENDO ALGUNS CONCEITOS OPERACIONAIS}

Inclusive as Fundações Públicas de direito público, que são entidades autárquicas.

2 Nesse sentido, não difeririam muito das fundações públicas de direito privado, pois como observa Matheus
Comecemos definindo, ainda que apenas para fins operacionais, em que consiste a Administração Pública. Segundo ensina Hely Lopes Meirelles (2016, p. 68), Administração Pública pode ser pensada em três sentidos: a) sentido formal: "conjunto de órgãos instituídos para consecução dos objetivos do Governo"; b) sentido material: "conjunto das funções necessárias aos serviços públicos em geral"; c) sentido operacional: "desempenho perene e sistemático, legal e técnico, dos serviços próprios do Estado ou por ele assumidos em benefício da coletividade". Em sentido não muito diverso, Diógenes Gasparini define Administração Pública - grafada em maiúsculas - como sendo sinônimo de Estado, e administração pública, significando atividade administrativa ou função administrativa.

O Decreto-Lei 200, de 25 de fevereiro de 1967, em seu art. $4^{\circ}$, por sua vez, estabelece a Administração Direta, "que se constitui dos serviços integrados na estrutura administrativa da Presidência da República e dos Ministérios"; e a Administração Indireta, que compreende as pessoas jurídicas criadas pela Administração Direta, ou seja, entidades, como Autarquias, Fundações Públicas, Empresas Públicas e Sociedades de Economia Mista.

A Administração Direta cria, portanto, outras pessoas jurídicas, as quais integram a Administração Indireta. Essas pessoas da Administração Indireta podem ser de direito público ou de direito privado. Grosso modo, podemos dizer que as pessoas jurídicas de direito público são criadas por Lei para desenvolver atividades típicas de Estado, ${ }^{1}$ e as pessoas jurídicas de direito privado, notadamente as empresas estatais, que podem ser criadas com a finalidade de prestação de serviços públicos ou de exploração de atividades econômicas de interesse da sociedade. ${ }^{2}$

As empresas estatais são constituídas na forma de Empresas Públicas, cujo capital é totalmente público, e podem ser constituídas sob qualquer forma empresarial permitida por lei. As Sociedades de Economia Mista, por seu turno, possuem capital misto, sendo que a maioria do capital votante é público e elas devem ser constituídas, necessariamente, na forma de Sociedade Anônima (S/A).

Compreendidos esses conceitos iniciais, convém fazer algumas considerações sobre o funcionamento da Administração Pública no Brasil, recorrendo, para isso, a três tipos ideais bastante recorrentes: Administração patrimonialista, burocrática e gerencial.

Carvalho: "as fundações públicas poderão ser instituídas com personalidade jurídica de direito privado, para execução de atividades de interesse social" (CARVALHO, 2019, p. 204). 
É comum se falar em três modelos de administração pública no Brasil, a administração patrimonialista, a administração burocrática, e a administração gerencial ou Nova Administração Pública - NAP. Essa é uma ideia bastante recorrente, aparecendo em Dissertações de Mestrado ( $c f$. TREVISAN, 2008), manuais de Direito Administrativo ( $c f$. ALEXANDRE; DEUS, 2015) e até mesmo em documentos oficiais, como é o caso do Plano Diretor da Reforma do Aparelho do Estado (cf. BRASIL, 1995). Para Andrei Trevisan (2008), a fase patrimonialista remonta a colonização e vai de 1500 até 1930, quando a Administração Pública começa a se burocratizar, em conexão com um contexto social e econômico mais amplo. A partir da Revolução de 30, "em função do processo de urbanização e industrialização, há um rearranjo político do Estado no sentido de atender às pressões modernizantes de uma incipiente burguesia nacional" (TREVISAN, 2008, p. 28). Teria surgido então, de acordo com o autor, A Administração Pública burocrática, que compreende os anos de 1930 a 1995 quando, a partir da chegada do ideário neoliberal, operaram-se as reformas tendentes a instalar o modelo gerencial de Administração Pública:

Nesta linha, o ideário neoliberal começa a penetrar no Brasil com mais força justamente a partir do início da década de 90. Este movimento trouxe consigo uma nova maneira de ver o papel do Estado e de conceber seu aparelho - isso culminaria no início do desmantelamento do Welfare State, não obstante a $\mathrm{CF} / 88$, haja vista as reformas e emendas constitucionais que vieram. $\mathrm{Na}$ administração pública o reflexo foi a adoção de técnicas advindas do mercado, consubstanciando-se a fase gerencialista, chamada atualmente de Nova Administração Pública (NAP). (TREVISAN, 2008, p. 39)

Esta Nova Administração Pública viria, portanto, de 1995 até os dias atuais. Se formos resumir, em poucas palavras, A Administração Pública patrimonialista seria uma herança direta do modelo português implantado no Brasil, sua principal característica seria uma prostituição do público em favor do privado, nas palavras de Sérgio Buarque de Holanda:

Para o funcionário "patrimonial”, a própria gestão política apresenta-se como assunto de seu interesse particular; as funções, os empregos e os benefícios que deles aufere relacionam-se a direitos pessoais do funcionário e não a interesses objetivos, como sucede no verdadeiro Estado burocrático, em que prevalecem a especialização das funções e o esforço para se assegurarem garantias jurídicas aos cidadãos. (HOLANDA, 2016)
Como podemos depreender da citação, a Administração Pública burocrática, por sua vez, não reconhece privilégios, é marcada pela impessoalidade, pelo império da Lei e dos procedimentos por ela definidos. Sempre é válido lembrar que um dos instrumentos que melhor atende à impessoalidade é o concurso público, pois, nas palavras de Hely Lopes Meirelles, "Pelo concurso afastam-se, pois, os ineptos e os apaniguados que costumam abarrotar as repartições, num espetáculo degradante de protecionismo e falta de escrúpulos de políticos que se alçam e se mantêm no poder leiloando cargos e empregos públicos" (MEIRELLES, 2016, p. 68).

A Administração Pública gerencial, por sua vez, fortemente inspirada em modelos de gestão empresarial, sacrifica parte desses procedimentos e formalidades em nome da eficiência, o que, no primeiro momento, parece razoável se pensarmos que o excesso de burocracia e formalismo pode, de fato, engessar a Administração Pública, retirando-lhe a efetividade.

Necessário observar que, na realidade, a administração patrimonialista nunca deixou de existir no Brasil. O patrimonialismo passou a permear os procedimentos burocráticos, o que faz com que permaneçam atuais as palavras de Sérgio Buarque de Holanda:

O funcionalismo patrimonial pode, com a progressiva divisão das funções e com a racionalização, adquirir traços burocráticos. Mas em sua essência ele é tanto mais diferente do burocrático, quanto mais caracterizados estejam os dois tipos.

No Brasil, pode dizer-se que só excepcionalmente tivemos um sistema administrativo e um corpo de funcionários puramente dedicados a interesses objetivos e fundados nesses interesses. Ao contrário, é possível acompanhar, ao longo de nossa história, o predomínio constante das vontades particulares que encontram seu ambiente próprio em círculos fechados e pouco acessíveis a uma ordenação impessoal. (HOLANDA, 2016).

Mesmo em sua fase burocrática a Administração Pública brasileira permaneceu sendo permeada por práticas patrimonialistas. É válido lembrar, a propósito, que a análise de Keith S. Rosenn sobre o jeito na cultura jurídica brasileira pode ser (re)pensada justamente na perspectiva de uma herança patrimonialista, já que, em todas as cinco modalidades principais apontadas pelo autor, o jeito se relaciona direta ou indiretamente à burla dos procedimentos burocráticos: 1) o servidor público deixa de cumprir sua obrigação em troca de vantagem; 2) o particular que utiliza de subterfúgios para fugir da lei; 3 ) o servidor que 
só cumpre o dever com presteza mediante remuneração; 4) o particular que burla uma lei irrealista, injusta ou economicamente ineficiente; 5) o servidor que foge da lei irrealista, injusta ou economicamente ineficiente (ROSENN, 1998).

Essa herança patrimonial permanece no modelo gerencial que se tenta implantar na Administração Pública, assim, diversos processos que deveriam ser de desburocratização e simplificação acabam se convertendo em formas de colocar o público a serviço de interesses privados, mais das vezes espúrios, assim é que propostas de reforma da Administração e da prestação de serviços públicos, incluindo-se aí a terceirização, embora revestidas de uma retórica de eficiência, na prática acabam alimentando a permanência do que poderia ser chamado de um modelo brasileiro de capitalismo: "patrimonialista e periférico" (GONÇALVES, 2017, p. 298).

\section{SOBRE TERCEIRIZAÇÃO NA ADMINISTRAÇÃO PÚBLICA: UMA PRIMEIRA APROXIMAÇÃ̃O}

Em uma primeira aproximação, identificamos que entre os dispositivos encontra-se o Projeto de Lei 4.330/2004, inspirador da norma aprovada em 8 de abril de 2015, o qual possibilitou a aprovação da Lei No. 13.467, de 13 de julho de 2017, mais conhecida como "reforma trabalhista" e entrou em vigor a partir de 11/11/2017. Ao regular o contrato de prestação de serviço e as relações de trabalho dele decorrentes, quando o prestador for sociedade empresária que contrate empregados ou subcontrate outra empresa para a execução do serviço, permitindo também a contratação de prestadoras de serviço por profissionais liberais, a norma abre expressamente a possibilidade de admissão do trabalho terceirizado até mesmo nas atividades-fim.

Logo em seguida, foi incorporada uma mudança que autoriza as Empresas Públicas e Sociedades de Economia Mista a contratar terceirizadas, ficando excluídas da regulamentação, a Administração Pública direta. Entretanto, a terceirização vem configurando-se como tendência também nos serviços públicos, em que a mencionada relação trilateral de trabalho tem sido adotada nas mais diversas áreas de atuação estatal, em detrimento do concurso público que, como sabemos, é instrumento hábil a afastar os ineptos e apaniguados da Administração.

Tema polêmico entre os jus laboralistas, a terceirização deve ser compreendida como estratégia do sistema capitalista para aumentar a produtividade e reduzir custos com a produção de mercadorias e serviços no contexto da globalização ou mundialização do capital, assim como parte das diretrizes neoliberais adotadas pelo Estado, visando o enxugamento dos gastos sociais, além do estímulo aos empreendedores, como endosso as atividades empresariais privados fornecedoras de mão de obra com baixa densidade regulatória ao mercado de trabalho.

Para os defensores da terceirização, que defendem que o contrato de prestação de serviços pode versar sobre o desenvolvimento de atividades inerentes, acessórias ou complementares à atividade econômica da contratante, a terceirização é uma técnica de administração do trabalho que visa atender à necessidade que a empresa moderna tem de se concentrar em seu negócio principal e na melhoria da qualidade do produto ou da prestação de serviço. Em resposta à crítica que se faz à terceirização no que se refere à precarização das relações e condições de trabalho dela decorrentes, entre outras disposições, se institui a responsabilidade subsidiária da contratante quanto às obrigações trabalhistas, assegurando-lhe o direito de ação regressiva contra a prestadora de serviços/devedora. No caso de contratação com a Administração Pública, especialmente tratada neste texto, encontramos que a Lei $\mathrm{n}^{\circ}$ 8.666, de 21 de junho de 1993, que regulamenta o artigo 37, inciso XXI, da Constituição Federal de 1988, que institui normas para licitações e contratos da Administração Pública e dá outras providências, determina a responsabilidade solidária da Administração Pública quanto aos encargos previdenciários, mas não quanto às dívidas trabalhistas.

Vale ressaltar que a investidura em cargo ou emprego público por meio de aprovação prévia em concurso público, com previsão no artigo 37, inciso II, da Constituição de 1988, visa à garantia de obediência aos princípios da isonomia, da moralidade e da impessoalidade, que devem nortear todos os atos da Administração Pública. A Súmula 331 do Supremo Tribunal Federal (STF), por sua vez, estabelece que a terceirização seja uma exceção, devendo ser utilizada apenas para trabalhos temporários, serviços de vigilância, conservação e limpeza, serviços especializados e atividades-meio do tomador de serviços. Apesar disso, o setor público é o maior contratador de serviços terceirizados no Brasil.

Ao manifestar seu entendimento sobre o assunto, o Tribunal de Contas da União vedou a terceirização de atividade-fim, recomendando a substituição paulatina dos terceirizados pelos concursados (Acórdão n. ${ }^{\circ}$ 1520/2006 - Plenário, Acórdão n. ${ }^{\circ}$ 1823/2006). No mesmo sentido, o Tribunal de Contas do Estado do Ceará (TCE) se posicionou contra a terceirização ilegal de serviços e funções inerentes a servidores efetivos, determinando a realização de concurso público. No Parecer Prévio às 
Contas de Governo do Exercício de 2011, este TCE recomendou que o Chefe do Executivo estadual adotasse medidas para rever o quadro de elevado índice de contração de mão de obra terceirizada. Mesmo assim, as despesas com terceirização em substituição a servidores aumentaram em $25,10 \%$ no exercício de 2012, em relação ao exercício de 2011. Diante desse quadro, o Ministério Público de Contas (MPC) fez as seguintes recomendações às Secretarias de Estado: que se abstenham de contratar terceirizados para a realização de atividades inerentes a servidores públicos (atividadesfim), sob pena de ofensa ao art. 37, II, CF/88; que utilizem a terceirização somente em atividades acessórias (apoio, limpeza e vigilância), desde que não haja substituição de servidores de carreira; que realizem as medidas necessárias à eliminação da terceirização de atividade-fim na administração pública estadual, com a substituição paulatina dos terceirizados pelos concursados; e que proíbam a indicação de nomes de profissionais para serem contratados por empresas fornecedoras de mão de obra terceirizada contratadas pelo Poder Público.

A terceirização, todavia, só tem aumentado no âmbito dos serviços públicos, trazendo graves implicações para os trabalhadores e usuários de tais serviços, uma vez que contribui para a fragmentação da classe trabalhadora, fragilização de sua organização sindical e precarização de suas condições de trabalho, além de prejudicar o funcionamento eficiente dos serviços sociais, que requerem força de trabalho permanente, capacitada e motivada, o que se torna difícil com a alta rotatividade e instabilidade de pessoal.

Feitas estas considerações iniciais, o presente artigo abordará, num primeiro tópico, os aspectos conceituais da terceirização, para além da perspectiva legalista, trazendo ao debate questões de ordem socioeconômica e política. Posteriormente, num segundo tópico, tratará dos aspectos jurídicos da referida forma de contratação, apresentando a legislação e o posicionamento de doutrinadores e juristas acerca do tema. Num terceiro tópico, apresentará algumas implicações da terceirização no âmbito da Administração Pública. Em seguida, far-se-ão as considerações finais, articulando os aspectos mencionados, no sentido de permitir ao leitor uma compreensão mais ampla do fenômeno da terceirização, sobretudo dos principais interesses que estão em jogo em seu processo de implementação e institucionalização no setor público brasileiro.

\section{FLEXIBILIZAÇÃO \\ TRABALHO E TERCEIRIZAÇÃO

$\begin{array}{lcc}\text { DAS } & \text { RELAÇÕES } & \text { DE } \\ \text { O } & \text { FENÔMENO } & \text { DA }\end{array}$

Um olhar diacrónico sobre o curso dos acontecimentos a partir dos anos 1970, permite compreender que o início de um cenário de crise de caráter estrutural - para a qual contribuíram o acirramento da concorrência internacional, a progressiva incorporação da revolução tecnológica ao processo de produção de mercadorias e serviços, o agravamento do desemprego, a retração do consumo, a queda da taxa de lucro e a crise fiscal do Estado - impôs ao capital a necessidade de desenvolver estratégias de restauração que envolveram profundas mudanças em suas formas de dominação econômica, política e ideológica (ANTUNES, 2000; BEHRING E BOSCHETTI, 2008).

Conforme observa Alves (1998, p. 118), nesse contexto, a expansão do mercado passa a exigir uma "coordenação política central", capaz de submeter os Estados nacionais à nova lógica da "acumulação planetária", tornando-se cada vez mais necessária a intervenção política de instituições do sistema Breton Woods, o Fundo Monetário Internacional (FMI) e o Banco Mundial, para evitar os "cataclismos financeiros" intrínsecos à globalização ou "mundialização do capital”, nos termos de Chesnais (1996). Desse modo, o Estado passa a viabilizar as condições de valorização e rentabilidade do capital transnacional em detrimento do atendimento às necessidades sociais e nacionais, ajustando-se à nova ordem capitalista mundial e às suas políticas macroeconômicas.

De acordo com Mészáros (2002, p. 107), a estrutura jurídica do Estado se coloca como "uma exigência absoluta para o exercício da tirania nos locais de trabalho". E a terceirização surge como tendência predominante na legitimação dessa tirania, viabilizandose por meio da maquinaria legal e político estatal, cujo papel é garantir e proteger as condições de reprodução e extração do trabalho excedente.

Segundo Rodrigo de Lacerda Carelli (2007), Procurador do Ministério Público do Trabalho no Rio de Janeiro, a terceirização é, atualmente, a maior fonte de problemas para o Direito do Trabalho. $\mathrm{O}$ uso desenfreado desta forma de contratação traz um crescimento extremado da precarização, que é disfarçada pela ideologia da "flexibilização" e encontra respaldo legal no aparelho jurídico estatal, o qual é ajustado para atender às exigências de mobilidade do capital, arrancar concessões passadas e garantir novas formas de controle das empresas sobre os trabalhadores. 
a flexibilização pode ser entendida como liberdade da empresa para desempregar trabalhadores, sem penalidades, quando a produção e as vendas diminuem; liberdade, sempre para a empresa, para reduzir o horário de trabalho ou de recorrer a mais horas de trabalho; possibilidade de pagar salários mais baixos do que a paridade de trabalho exige; possibilidade de subdividir a jornada de trabalho em dia e semana segundo as conveniências das empresas, mudando os horários e as características do trabalho (por turno, por escala, em tempo parcial, horário flexível etc.), dentre tantas outras formas de precarização da força de trabalho.

No Brasil, a terceirização ganha impulso com as mudanças decorrentes da reestruturação produtiva e do neoliberalismo, que afetam as garantias e os direitos sociais historicamente conquistados pela classe trabalhadora. Em razão da maior vulnerabilidade dos trabalhadores diante das ofensivas do capital, a luta pelo reconhecimento e a afirmação desses direitos se torna ainda mais desafiadora. Afinal, como assinala Telles (1999, p. 174), trata-se de "direitos que mal ou bem garantem prerrogativas que compensam a assimetria de posições nas relações de trabalho e poder, e fornecem proteções contra as incertezas da economia e os azares da vida".

$\mathrm{Na}$ sociedade brasileira, a concepção universalista dos direitos sociais foi incorporada na Constituição de 1988, considerada uma referência importante na história recente do País, uma vez que funda um projeto democrático após vinte e um anos de ditadura militar. Mas, no confronto desse projeto com o processo de ajustes liberais iniciado nos anos 1990, os direitos sociais instituídos são desregulamentados, atendendo-se às novas exigências de valorização e de acumulação capitalista.

Conforme assinala Telles, nesses "tempos de neoliberalismo vitorioso", não só se elide a responsabilidade do Estado, com o desmantelamento dos serviços públicos, como também se descaracteriza a própria noção de direitos, os quais são desvinculados do parâmetro da justiça e da igualdade, passando a ser "associados a custos e ônus que obstam a potência modernizadora do mercado, ou então a privilégios corporativos que carregam anacronismos que precisam ser superados para que o país possa se integrar nos circuitos globalizados da economia" (1999, p. 172). Isentando-se do seu papel de regulador da vida social e de garantidor de direitos, para assumir o papel de gerenciador do capital, o Estado acaba por legitimar a submissão dos trabalhadores às regras do mercado, por meio da redefinição do aparato legal que regulamenta as relações de trabalho.

Thébaud-Mony e Druck (2007) ressaltam que a terceirização é a principal dimensão da flexibilização e precarização do trabalho, pois permite uma dominação da força de trabalho pelo capital quase sem limites. Embora seja uma prática utilizada desde a Revolução Industrial, caracteriza-se, na atualidade, como um fenômeno renovado, ocupando lugar central nas novas estratégias de gestão e organização do trabalho. As formas mais recorrentes de terceirização no Brasil incluem: o trabalho em domicílio; a subcontratação de serviços considerados periféricos (transporte, limpeza, alimentação etc.); a subcontratação de empresas ou trabalhadores autônomos em áreas centrais da indústria (produção e manutenção); e a quarteirização ou "terceirização em cascata", constituída por empresas contratadas para gerir os contratos com as prestadoras de serviços.

Há, ainda, um crescente grupo de trabalhadores terceirizados formais, ou seja, aqueles que são contratados com carteira de trabalho assinada, mas nem por isto deixam de fazer parte do mercado de trabalho precário. De acordo com Pochmann (apud THÉBAUDMONY e DRUCK, 2007), estes trabalhadores recebem remuneração e benefícios inferiores aos do conjunto dos assalariados formais; costumam ser desvalorizados e discriminados em relação aos trabalhadores efetivos ou permanentes; são desrespeitados quanto ao cumprimento e aplicação dos programas de saúde e segurança no trabalho; e encontram maiores dificuldades de se organizar coletivamente, devido à dispersão, rotatividade e instabilidade típicas de sua condição de terceirizados.

Impõem-se, assim, sérias dificuldades aos organismos de representação da classe trabalhadora, sobretudo aos sindicatos, que têm o desafio de inserir em suas lutas e reivindicações os interesses do conjunto de trabalhadores, inclusive os desempregados e precarizados. Afinal, o sindicalismo não ficou imune às transformações ocorridas nas últimas décadas, mas, pelo contrário, foi profundamente afetado por elas, mudando o seu discurso e as suas estratégias de ação frente às velhas e novas ofensivas do capital, as quais não têm apenas um conteúdo econômico, no sentido de reduzir custos e aumentar a lucratividade, mas também um forte conteúdo político, uma vez que fragmentam a classe trabalhadora e fragilizam, assim, sua capacidade organizativa.

\section{ASPECTOS NORMATIVOS TERCEIRIZAÇÃO NO BRASIL}

DA

Vólia Cassar (2014) define terceirização como a relação trilateral formada entre trabalhador, intermediador (ou empregador aparente) e o tomador de serviços (ou empregador real), caracterizada pela não coincidência do empregador real com o formal. Para a 
autora, a subcontratação de empregados contraria a finalidade, a função social e os princípios do Direito do Trabalho, tais como os da proteção ao empregado (que tem status constitucional e convencional, o primeiro previsto no ar. $7^{\circ}$, caput, da Constituição Federal de 1988), e os segundos na Convenção No. 158, da Organização Internacional do Trabalho, instrumentos que inspiram a principiologia que norteia o Direito do Trabalho, nas quais se inserem os conceitos "da condição mais benéfica", "do tratamento isonômico" entre os trabalhadores que prestam serviço a uma mesma empresa e da ajenidad, isto é, da bilateralidade dos contratos de trabalho.

Entre as hipóteses de terceirização admitidas no ordenamento jurídico brasileiro, a autora destaca as regulamentadas pelos seguintes dispositivos: artigo 455 da Consolidação das Leis do Trabalho (CLT), que permite a subcontratação de operários pelo empreiteiro principal, dono do empreendimento; Lei $\mathrm{n}^{\circ}$ 6.019/1974, que autoriza a intermediação de mão de obra para atender necessidade transitória de substituição de pessoal regular e permanente do tomador de serviços; Lei $n^{\circ} 7.102 / 1983$, que dispõe sobre a terceirização dos serviços de vigilância; artigo 442, parágrafo único, da CLT, que afirma a inexistência de vínculo entre os associados da cooperativa e os tomadores de serviços; Súmula $\mathrm{n}^{\circ} 331$, inciso III, do Tribunal Superior do Trabalho (TST), que dispõe sobre a terceirização de atividades ligadas à atividade-meio, desde que inexistente a pessoalidade e a subordinação; artigo 25 da Lei $n^{\circ} 8.987 / 1995$, que dispõe sobre a terceirização de atividades acessórias, não inseridas na atividade-fim, desde que inexistentes a pessoalidade e a subordinação; e, claro, o artigo 37, inciso II, da Constituição Federal (CRFB/1988), que, ao estabelecer a exigência de prévia aprovação em concurso público para investidura em cargo ou emprego público, fomenta amplas e irrestritas hipóteses de terceirização por parte dos entes públicos que, diante da urgência em contratar mão de obra para serviços essenciais à comunidade, não poderiam esperar pela criação de cargos por lei ou pelo concurso público. Neste caso, a contratação de trabalhadores por meio de empresa colocadora de mão de obra, ainda que irregular e contrária à lei, não implica a formação do vínculo com o tomador público, dado o óbice constitucional (CASSAR, 2014).

3 O Decreto Lei $\mathrm{n}^{\circ}$ 200, de 25 de fevereiro de 1967, dispõe sobre a organização da Administração Federal, estabelece diretrizes para a Reforma Administrativa e dá outras providências. Em seu artigo 10, estabelece: "A execução das atividades da Administração Federal deverá ser amplamente descentralizada". O $\S 7^{\circ}$ determina que: "Para melhor desincumbir-se das tarefas de planejamento, coordenação, supervisão e controle e com o objetivo de
No tocante à Administração Pública, a Constituição da República Federativa do Brasil (CRFB) determina, em seu artigo 37, inciso II, que "a investidura em cargo ou emprego público depende de aprovação prévia em concurso público de provas ou de provas e títulos, de acordo com a natureza e a complexidade do cargo ou emprego, na forma prevista em lei". Desse modo, afirma a autora:

Ora, se os cargos destinados às funções relacionadas com a atividade-meio, tais como conservação, limpeza, preparo de alimentação etc., não podem ser criados por lei, e, se são essenciais para o funcionamento da administração pública, outra alternativa não resta que a de cumprir o disposto no $\S 7^{\circ}$ do art. 10 do Decreto Lei $n^{\circ}$ $200 / 67^{3}$, isto é, de terceirizar esses trabalhadores. Portanto, se a Administração Pública necessitar de ascensoristas, garçons, copeiras, faxineiros etc., deverá terceirizar. (CASSAR, 2014, p. 486).

Mas, o que dizer de atividades-fim da Administração Pública, tais como aquelas relacionadas à prestação de serviços essenciais, como saúde, justiça, habitação e assistência social? $O$ que justifica a terceirização de médicos, psicólogos, assistentes sociais e outros profissionais cujas atividades são indispensáveis ao planejamento e à execução de tais serviços? Por que não se criam cargos e não se realizam concursos públicos para garantir a eficiência e a qualidade dos mesmos, atendendo, assim, às demandas da população usuária? Será que a Administração Pública pode fraudar o concurso público, em detrimento dos direitos dos trabalhadores e da população em geral, privando-lhes do acesso a serviços públicos de qualidade? Estas são algumas questões que devem ser pensadas quando o assunto é ilicitude ou irregularidade da terceirização.

Ainda segundo Cassar (2014), as terceirizações devem ser classificadas como regulares e irregulares, e não como lícitas ou ilícitas, como o fazem alguns autores, uma vez que não há lei que as proíba. São consideradas regulares as terceirizações ligadas às atividades-meio, quando estiverem ausentes os requisitos do vínculo de emprego entre o trabalhador e o tomador, ou as terceirizações realizadas pela Administração Pública mediante contrato por licitação em caso de necessidade, desde que não haja fraude ao

impedir o crescimento desmesurado da máquina administrativa, a Administração procurará desobrigar-se da realização material de tarefas executivas, recorrendo, sempre que possível, à execução indireta, mediante contrato, desde que exista, na área, iniciativa privada suficientemente desenvolvida e capacitada a desempenhar os encargos de execução". 
concurso público

Já as terceirizações irregulares são aquelas que, mesmo não proibidas por lei (lícitas), violam princípios básicos de Direito do Trabalho ou de Direito Administrativo, como por exemplo, a terceirização de atividade-fim nos casos em que o vínculo não se forme com o tomador dos serviços em virtude do rodízio de trabalhadores ou da falta de pessoalidade; ou quando a lei impede a formação do vínculo com o tomador, embora haja pessoalidade, no caso da Administração Pública. Portanto, conforme a autora supracitada,

O correto seria a realização de concurso público para o preenchimento das vagas existentes, mas se comprovada a real impossibilidade de realização do certame, é melhor aceitar a subcontratação que impedir a contratação para determinadas áreas que atendam o interesse público. $\mathrm{O}$ próprio Ministério Público do Trabalho tolera esse tipo de contratação. Mas tal procedimento deve ser analisado com bastante cautela para impedir que a Administração Pública sempre utilize o argumento de impossibilidade de realizar concurso público para se beneficiar com esse tipo de contratação (CASSAR, 2014, p. 488).

De acordo com Jorge Neto e Cavalcante (2013), desde os anos 1970, a prática da prestação de serviços prosseguiu sem restrições jurisprudenciais, até que o Tribunal Superior do Trabalho (TST) emitisse a Súmula 256, em setembro de 1986, segundo a qual era considerada ilegal a contratação de trabalhadores por empresa interposta, formando-se o vínculo empregatício diretamente com o tomador dos serviços, salvo nos casos de trabalho temporário e de serviço de vigilância, previstos nas Leis 6.019/1974 e 7.102/1983, respectivamente. Percebe-se, entretanto, que a tendência à flexibilização das relações de trabalho também se reflete na jurisprudência. Daí a substituição da Súmula $n^{\circ} 256$ pela Súmula $n^{\circ} 331$ do TST, com redação determinada pela Resolução ${ }^{\circ} 174$, de 24 de maio de 2011, que dispõe sobre a legalidade do contrato de prestação de serviços.

Por meio desta última súmula, o TST firmou entendimento no sentido de permitir que a Administração Pública contrate prestadores de serviços, observando-se as condições a seguir: não se admite a terceirização em atividade-fim, ou seja, fica a Administração proibida de contratar trabalhadores por empresa interposta, entretanto, como o artigo 37, inciso II, da CF/1988 determina a prévia realização de concurso público para contratação de servidores e empregados

$4 \quad$ Lei da terceirização é a maior derrota popular desde o golpe de 64. Disponível em: públicos, não há como reconhecer o vínculo desses trabalhadores com o ente público; admite-se a terceirização em atividade-meio da Administração Pública, desde que precedida pelo regular procedimento licitatório, como, por exemplo, nas atividades de limpeza, conservação, vigilância, telefonia etc., e desde que inexistentes a pessoalidade e a subordinação; nas terceirizações regulares permitidas (isto é, de atividadesmeio) surge para o tomador de serviços a responsabilidade subsidiária pelo inadimplemento das obrigações trabalhistas por parte do empregador prestador de serviços, em caso de não fiscalizar a execução do contrato (SARAIVA \& SOUTO, 2014, p. 345-347).

Jorge Neto e Cavalcante (2013) chamam atenção para o fato de que pode haver fraude na própria contratação, quando o prestador se apresenta como um intermediário do ponto de vista formal, sendo a empresa tomadora o verdadeiro empregador. Nesse sentido, a Súmula 331 do TST menciona que a terceirização só é regular quando inexiste a pessoalidade e a subordinação direta, ou seja, quando os serviços contratados podem ser executados por qualquer profissional indicado pela empresa interposta, podendo haver, por exemplo, remanejamento de trabalhadores em caso de férias, faltas, licenças médicas etc. Outro aspecto ressaltado pelos autores refere-se ao fato de que só se admite a terceirização de atividades intermediárias ou atividadesmeio, que consistem no apoio a setores interligados ao processo produtivo dentro da tomadora, isto é, atividades periféricas à essência da dinâmica empresarial. A jurisprudência consolidada na referida súmula menciona, portanto, que a empresa tomadora não proceda à terceirização nas suas atividades-fim, as quais correspondem a funções e tarefas que se ajustam ao núcleo da dinâmica empresarial do tomador de serviços.

Para os autores supracitados, entretanto, não existem restrições para que a terceirização também ocorra nas atividades-fim da tomadora de serviços, tendo em vista que se trata de um fenômeno global da economia mundial, à qual o Brasil está interligado. Nesse sentido, o Projeto de Lei $n^{\circ} 4.330 / 2004$, que tramitou no Congresso Nacional e foi aprovado pela Câmara dos Deputados em abril de 2015, visa regular os contratos de terceirização, pondo fim aos limites ao tipo de serviço que pode ser terceirizado, isto é, tem como cerne a permissão para que as empresas terceirizem qualquer atividade da cadeia produtiva, inclusive atividades-fim, desde que a empresa terceirizada se especialize na oferta de um único serviço.

Em verdade, como afirma Ruy $\mathrm{Braga}^{4}$, não é

http://www.cartacapital.com.br/economia. Acesso em: maio/2015. 
necessária uma lei para regular a terceirização, pois a Súmula 331 do TST pacificou na Justiça o consenso de que não se podem terceirizar as atividades-fim. O que acontece é que as empresas não se conformam com esse fato, já que seu maior interesse é aumentar os lucros. Segundo ele, a terceirização fecha postos de trabalho, diminui a remuneração dos empregados, prejudica a sindicalização, bloqueia o acesso a direitos trabalhistas e aumenta o número de mortes e acidentes no trabalho, já que a rigidez da fiscalização é menor por empresas subcontratadas. Essa prática também pressiona a massa salarial, pois, a cada demissão, alguém é contratado por um salário menor, fazendo com que a rotatividade aumente ano após ano. Ademais, a arrecadação de impostos também pode ser afetada, uma vez que, no Brasil, o trabalhador terceirizado recebe $30 \%$ menos do que aquele diretamente contratado e, com o avanço das terceirizações, o Estado naturalmente arrecadará menos.

Seguindo a diretriz da descentralização administrativa, a Administração Pública vem aderindo à terceirização desde os anos 1970, intensificando essa prática nas últimas décadas, embora a Carta Magna de 1988 tenha estabelecido, no artigo 37, inciso II, o concurso público de provas ou de provas e títulos como requisito indispensável para a investidura em cargo ou emprego público na Administração Pública direta e indireta em todas as esferas políticas (União, Estados, Distrito Federal e Municípios), salvo nas hipóteses de cargo de provimento em comissão e outras exceções constitucionais $^{5}$. O referido dispositivo constitucional tem como finalidade assegurar a igualdade entre os participantes e garantir que os aprovados sejam pessoas capazes e competentes, além de dar transparência à Administração Pública e evitar prejuízo dos serviços públicos ${ }^{6}$. Entretanto, a terceirização tem sido a regra, enquanto o concurso público tem sido a exceção na Administração Pública, trazendo sérios prejuízos para trabalhadores e usuários dos serviços sociais prestados pelo Estado.

Também são exceções ao concurso público: a nomeação dos membros dos Tribunais de Contas da União; o 1/5 Constitucional, composto de membros do Ministério Público e de advogados nos tribunais; membros do Supremo Tribunal Federal (STF), Superior Tribunal de Justiça (STJ); Tribunal Superior Eleitoral (STE) e Superior Tribunal Militar (STM) - arts. 7, § 2º 94, 101, 104, parágrafo único, XII, 107, 111-A, I, 119, II, 120, III, e 123); a contratação emergencial (art. 37, IX, CF/1988), quando se tem apenas um processo seletivo (JORGE NETO e CAVALCANTE, 2013, p. 443).

6 Carvalho Filho (2008, p. 293) conceitua serviço

\section{IMPLICAÇÕES DA TERCEIRIZAÇÃO NO ÂMBITO DA ADMINISTRAÇÃO PÚBLICA}

Conforme assinala Delgado (2004, p. 428), a terceirização é o fenômeno "pelo qual se dissocia a relação econômica de trabalho da relação jus trabalhista que lhe seria correspondente". Segundo o autor, o modelo trilateral de relação jurídica que surge com a terceirização - obreiro, empresa terceirizante e tomadora de serviços - traz graves desajustes em relação aos objetivos tutelares e redistributivos que caracterizam o Direito do Trabalho.

Apesar de a doutrina e a jurisprudência jus trabalhistas enxergarem na terceirização uma modalidade excetiva de contratação de força de trabalho, nas últimas décadas este fenômeno tem-se tornado tendência crescente nas relações de trabalho no Brasil, inclusive no âmbito da Administração Pública. Esta última, do ponto de vista objetivo, diz respeito à gestão dos interesses públicos executada pelo Estado, cuja "destinatária é a própria sociedade, ou seja, os indivíduos, com vistas a sua proteção, segurança e bemestar"; já no sentido subjetivo, significa "o conjunto de agentes, órgãos e pessoas jurídicas que tenham a incumbência de executar as atividades administrativas" (CARVALHO FILHO, 2008, p. 9).

Na década de 1940, à época da elaboração da CLT, a terceirização não tinha a abrangência que passou a ter nos últimos trinta anos do século XX. O referido diploma apenas fazia ligeiras menções a duas figuras de subcontratação de mão-de-obra: a empreitada e subempreitada e a pequena empreitada. Somente no final dos anos 1960 e início dos anos 1970 o fenômeno passa a ter referência na ordem jurídica, com o Decreto Lei $n^{\circ}$ 200/1967 (artigo 10) e a Lei $\mathrm{n}^{\circ} 5.645 / 1970$, que estimulam a prática da descentralização administrativa por meio da contratação de serviços meramente executivos e operacionais mediante empresas privadas, referindo-se à administração direta e indireta da União, dos Estados e dos Municípios. Assim, é nas relações de trabalho estatais que ocorrem as primeiras referências

público como "toda atividade prestada pelo Estado ou por seus delegados, basicamente sob regime de direito público, com vistas à satisfação de necessidades essenciais e secundárias da sociedade". Já os serviços sociais “são os que o Estado executa para atender aos reclamos sociais básicos e representam ou uma atividade propiciadora de comodidade relevante, ou serviços assistenciais e protetivos" (Idem, p. 296). São exemplos de serviços sociais a assistência à criança e ao adolescente, a assistência médica e hospitalar, a assistência educacional etc. Em tais serviços, as relações de trabalho terceirizadas têm sido predominantes, contrariando determinações constitucionais. 
legais sobre terceirização, ainda sem esta denominação. Com a Lei do Trabalho Temporário (Lei $n^{\circ}$ 6019/1974), o fenômeno foi estendido ao campo privado. A Lei $\mathrm{n}^{\circ}$ 7.102/1983 autorizou a terceirização do trabalho de vigilância bancária, em caráter permanente, e, no decorrer dos anos 1980 e 1990, independentemente de texto legal autorizativo, as práticas de terceirização foram crescentemente incorporadas pelas empresas capitalistas, principalmente na área de conservação e limpeza, tornando-se cada vez mais frequentes.

Como ressalta Souza (2015), no setor público, a terceirização significa o trespasse de execução de atividades de órgãos e entes da Administração Pública para terceiros sob a forma de contrato de prestação de serviços. Segundo ele, duas são as modalidades de terceirização especificadas pela doutrina: a temporária, cuja finalidade é atender demandas passageiras, sem restrição quanto à natureza da atividade objeto da contratação; e a permanente, que está voltada ao atendimento de necessidades de caráter não transitório.

De acordo com a jurisprudência sumulada do TST, a terceirização permanente só é legítima quando envolve as atividades de vigilância, conservação e limpeza, bem como as demais atividades-meio, desde que não haja pessoalidade e subordinação direta, ou seja, não pode ser transferido ao tomador de serviços o poder diretivo do empregador-prestador, o qual, pelo que dispõe $o$ art. $2^{\circ}$ da CLT, desdobra-se no poder de comando, no poder regulamentar e no poder disciplinar. Também deve estar ausente a pessoalidade, isto é, não deve haver um interesse na condição pessoal daquele que presta o serviço. Não observados estes aspectos, previstos nos itens I e III da Súmula 331, considera-se ilícita a terceirização.

A consequência natural em caso de ilicitude seria a formação de vínculo empregatício direto entre trabalhador e tomador de serviços. Todavia, quando o tomador é a Administração Pública, afasta-se esta consequência, ante a necessidade de concurso público, conforme artigo 37, II, da CF/1988 e item II da Súmula 331. Delgado (2004) acredita que, em caso de terceirização ilícita praticada por entidades da Administração Pública, a resposta está na observância da isonomia, o que significa assegurar ao trabalhador terceirizado todas as verbas trabalhistas legais e normativas aplicáveis ao empregado estatal direto que cumpra a mesma função no ente estatal tomador dos serviços, sem, contudo, retificar a Carteira de Trabalho e Previdência Social (CTPS) quanto à entidade empregadora formal, já que isto é objeto de expressa vedação constitucional.

Desse modo, a terceirização deve ser entendida como uma forma de contratação de serviços auxiliares e de apoio à atividade estatal, que possibilite ao gestor público concentrar-se nas atividades e serviços principais da Administração Pública, e não como meio de burlar o concurso público. No entanto, é cada vez mais comum encontrar casos de fornecimento de mãode-obra ao Estado sob a denominação de prestação de serviços técnicos especializados, quando, de fato, deveria ser realizado o concurso público. Tal ato simulado, conforme enfatizam Marcos Ribeiro Salvino e Simone Rodrigues Ferreira (apud SOUZA, 2015), além de mascarar a relação jurídica de emprego própria da atividade estatal e ensejar fraude aos direitos trabalhistas, viola o interesse público e favorece o clientelismo político e a corrupção, o que se torna especialmente problemático em um país como o Brasil, cuja Administração Pública, já vimos, possui um histórico fortemente patrimonialista.

Os profissionais terceirizados revelaram que a terceirização dos serviços públicos tem como principais implicações: instabilidade no emprego, o que aumenta a insegurança profissional; deficiência salarial e falta de garantia de direitos trabalhistas, em comparação aos servidores concursados; demissões decorrentes de mudanças de governo, aumentando a subordinação política dos terceirizados e os envolvendo em relações de poder; falta de liberdade e autonomia para expor suas ideais e opiniões, bem como para defender princípios e valores ético-profissionais; falta de incentivo e estímulo à qualificação profissional e/ou à educação permanente, fazendo com que profissionais tenham de deixar a instituição para cursar uma pós-graduação, por exemplo; alta rotatividade dos profissionais, o que interfere diretamente na relação com os usuários, no acompanhamento dos casos, na continuidade das ações e dos serviços; condições precárias de trabalho, que impossibilitam os terceirizados de vislumbrar o produto final do seu trabalho e os objetivos que pretendem alcançar.

Souza (2015) observa, ainda, que, com a terceirização, há uma progressiva desprofissionalização da Administração Pública, com a eliminação de carreiras necessárias ao adequado exercício das atividades estatais, que se fazem substituir por profissionais pouco qualificados e em frequente rotação, mediante contratação de cooperativas e outras organizações sociais muitas vezes destituídas de expertise.

A isonomia salarial é outro aspecto importante no debate sobre a terceirização. De acordo com Delgado (2004), as vantagens salariais e normativas devem ser equitativas para empregados da mesma categoria, quer sejam trabalhadores diretamente contratados pela tomadora de serviços, quer sejam terceirizados, tendo em vista mitigar o caráter antissocial da terceirização, que, sem tal isonomia, consiste numa fórmula de aviltamento de salários e do padrão social dos trabalhadores. Para o 
autor, a discriminação socioeconômica é inadmissível, vez que fere a própria dignidade do trabalhador, e, em caso de terceirização permanente, como vem ocorrendo nos serviços públicos essenciais, "a perversidade da discriminação é muito mais grave, profunda e constante" (DELGADO, 2004, p. 445). A fala seguinte revela que a remuneração dos profissionais terceirizados, além de não contemplar direitos trabalhistas aos quais têm acesso trabalhadores que exercem as mesmas atribuições em condições distintas de contratação, não corresponde à complexidade do trabalho por eles realizado, o qual requer a mesma dedicação e competência exigidas de um servidor público concursado.

Quanto à remuneração, a gente que trabalha no campo sociojurídico, principalmente com adolescentes autores de atos infracionais, é da mesma forma que trabalhar em presídio (...) Os assistentes sociais de presídios geralmente recebem por periculosidade (...) como nós somos terceirizadas, a gente não recebe. (...) O salário é reduzido frente a outras Secretarias. (...) A unidade é para ter sessenta adolescentes; hoje o número é triplicado. (...) A falta de profissional realmente atrapalha o nosso trabalho. Tem dias que chegam doze adolescentes, então o atendimento que a gente pode fazer é um atendimento rápido, que muitas vezes não dá conta de compreender realmente aquela realidade do adolescente. (Assistente social terceirizada, Centro Sócio educacional/STDS). (DELGADO, 2004 p. 446).

Desse modo, a terceirização atinge duplamente a classe trabalhadora: quanto aos direitos trabalhistas, desregulamentados sob o argumento da flexibilização das relações de trabalho; e quanto ao acesso aos serviços públicos, cuja eficiência e qualidade restam prejudicadas, dadas a elevada rotatividade dos trabalhadores que neles atuam e as precárias condições de trabalho a que são submetidos.

\section{OS IMPACTOS DA Lei No. 13.429/17}

A Lei $n^{\circ} 13.429$ de 2017, que alterou a Lei ${ }^{\circ}$ 6.019 de 1974, que, por sua vez, regulara o trabalho temporário, traz um novo panorama legal para os direitos trabalhistas, pois reordenou in pejus, segundo interpretação de Azevedo (2014, p.324), “(...) todas as frágeis limitações existentes à terceirização, a exemplo do Enunciado n. 331 do Tribunal Superior do Trabalho, que impede a terceirização da atividade-fim da empresa".

Ao haver o contrato de terceirização para com a Administração Pública, o amparo ao trabalhador tornase diferenciado, não apenas e principalmente pela aplicação ou não da lei n. 6.019, mas também porque não há de se falar em vínculo de emprego com aquela, caso seja verificado que esteja havendo os requisitos de emprego diretamente entre o ente público e o empregado terceirizado.

Ao haver o contrato de terceirização para com a Administração Pública, o amparo ao trabalhador tornase diferenciado, pois não há de se falar em vínculo de emprego formal, se verificado que esteja havendo os requisitos de emprego diretamente entre o ente público e o empregado terceirizado.

Como a regra constitucional de contratação para a Administração Pública é o concurso público, pelo artigo 37 da Constituição, não se admite o reconhecimento de vínculo pela fraude da terceirização, assim como ocorre com os entes particulares, em mesma situação.

Quanto a Administração Pública, não ficou evidente se a mesma se enquadra nesta alteração legislativa da Terceirização, vez que não há qualquer referência à Administração Direta ou Indireta, seja admitindo ou proibindo tal prática.

O Supremo Tribunal Federal - STF enfrentou a discussão da terceirização em ADPF n ${ }^{\circ}$ 324/DF e RE 958.252, de forma conjunta, com repercussão geral, no ano de 2018. Tais ações analisaram, respectivamente, as controvérsias judiciais existentes entre a abrangência excessiva da Súmula 331 do TST e a ausência de previsão legal que efetivamente limite a terceirização na atividade fim, e a ilicitude, propriamente dita, da terceirização em face desta mesma súmula.

Analisou-se, portanto, a constitucionalidade da terceirização, sua compatibilidade e agressão a preceito fundamental, chegando à conclusão de que aquela exercida na atividade fim é, de fato, constitucional. Utilizou-se, ainda, para determinar nova interpretação sobre a Sum. 331 do TST, a qual por muito tempo era o principal instrumento normativo norteador desta modalidade de contratação, declarou-a como superada.

Especificamente, o Ministro Luiz Fux, na tese de repercussão geral, propôs a licitude da terceirização ou qualquer outra forma de divisão do trabalho em pessoas jurídicas distintas. É o caso de desconcentração produtiva, na qual há a descentralização da cadeia de produção. Entretanto, não declarou superada por completo, mas apenas sua inconstitucionalidade parcial, referente aos incisos I, III, IV e VI, ou que tal súmula fosse alterada imediatamente de forma consoante ao novo preceito legislativo que foi a alteração da lei do trabalho temporário, Lei ${ }^{\circ} 6.019$.

Dentre estes incisos está a limitação à atividade-meio e a responsabilidade da tomadora de serviços, não alterando a possibilidade para a Administração Pública direta e indireta.

O Supremo argumentou que a súmula 331 seria 
uma intervenção imotivada na liberdade jurídica de contratar sem restrição. Os valores sociais do trabalho estariam em igual patamar com a livre iniciativa e, portanto, como fundamentos do Estado Democrático de Direito, conectados, o que impediria a valorização de um em detrimento do outro. Assim, as intervenções do Estado deveriam ser as mínimas possíveis, pois estes não violariam qualquer direito constitucional, pelo contrário, trariam benefícios como a especialização de serviços, a desconcentração de etapas produtivas da organização, o estímulo à concorrência de fornecedores e a maior facilidade de adaptação às necessidades de modificações estruturais.

O Ministro Celso de Mello corroborou com este entendimento, defendendo que a liberdade do modo de contratação é faculdade do empregador.

[...] sendo inadmissível a criação de obstáculos genéricos a partir da interpretação inadequada da legislação constitucional e infraconstitucional em vigor, que resulte na obrigatoriedade de empresas estabelecidas assumirem a responsabilidade por todas as atividades que façam parte de sua estrutura empresarial. (Voto Ministro Celso de Melo ADPF $n^{\circ}$ 324/DF e RE 958.252)

Para o ministro, a terceirização é instrumento para a retomada do crescimento, pois resulta em redução de custos para as empresas. Além disso, também é ferramenta para a criação de novos postos de trabalho e a geração de mais empregos, suficientes para auxiliar o país a retomada do crescimento e superar a crise econômica. "Os atos do Poder Público, à guisa de proteger o trabalhador, poderão causar muitos prejuízos ao trabalhador, pois nas crises econômicas diminuem consideravelmente os postos de trabalho" (Voto Ministro Celso de Melo ADPF no 324/DF e RE 958.252).

A revogação dos citados incisos remete a aplicação plena e sem contradição normativa da lei $\mathrm{n}^{\circ}$ 6.019 , lei do trabalho temporário, pois também prevê as regras de responsabilidade das obrigações trabalhistas e requisitos para a aplicação subsidiária do tomador de serviços, tais como a participação na relação processual e constar em título executivo judicial, além da formação de vínculo de emprego em caso de fraudes.

Por outro lado, o STF aboliu algumas restrições à terceirização, inclusive no âmbito público. Com tais modificações, cabe investigar as alterações legislativas sobre $o$ assunto, sua aplicação à Administração Pública, bem como sua influência através do patrimonialismo, como forma de controle para benefícios privados da máquina pública, e nas novas modalidades de trabalho, a fim de evitar a precarização.

Neste sentido, com a ausência dos referidos incisos da súmula 331, do TST, com a nova interpretação do STF e com a alteração da lei 6.019, surge a incerteza de aplicação das novas regras infraconstitucionais de terceirização à Administração Pública. Sua inclusão não está especificada no texto legislativo.

A aplicação de leis para entes privados e entes públicos é diferenciada em diversos aspectos, tais como os definidos no PL 4.330 que prevê a aplicação da terceirização apenas para as Empresas Públicas e Sociedades de Economia Mista da Administração Pública Indireta, em virtude do caráter público, mas com atividades particulares, ou mesmo do capital parcialmente particular.

Inclui-se neste rol diversas e grandes entidades brasileiras, as quais tem papel fundamental na economia e são de destaque internacional, como por exemplo o Banco do Brasil, a Caixa Econômica Federal e a Petrobrás.

Ressalte-se que a Constituição Federal, em seu art. $173, \S 1^{\circ}$, reservou às Empresas Públicas e Sociedades de Economia Mista, a possibilidade de exercerem atividade econômica ou prestação de serviços, o que garante caráter mais sério a implantação da terceirização, pois trata-se de empresas de atividade social e de grande capital Estatal. O art. $5^{\circ}$, incisos II e III, do DL 200/67 estabelecem os conceitos destas duas entidades da Administração Indireta:

Empresa Pública - a entidade dotada de personalidade jurídica de direito privado, com patrimônio próprio e capital exclusivo da União, criado por lei para a exploração de atividade econômica que o Governo seja levado a exercer por força de contingência ou de conveniência administrativa podendo revestir-se de qualquer das formas admitidas em direito.

Sociedade de Economia Mista - a entidade dotada de personalidade jurídica de direito privado, criada por lei para a exploração de atividade econômica, sob a forma de sociedade anônima, cujas ações com direito a voto pertençam em sua maioria à União ou a entidade da Administração Indireta (D.L.200/1967).

Analisando estas definições, Medauar (2014, p.105-108) esclarece que ambas as entidades podem prestar atividades de caráter econômico, no entanto existem muitas que prestam serviços públicos. Logo, cabe à lei, que estabelecer o estatuto destas entidades, definir a atividade que será exercida, conforme o citado artigo $173 \S 1^{\circ} \mathrm{da} \mathrm{CF} / 88$.

No âmbito da Administração Pública a terceirização é regida também pela Lei no 8.666 de 1993 - Lei de Licitações e Contratos da Administração Pública. Trata-se de execução de atividade pública que é 
realizada pela contratação de terceiros. Para fiscalizar esta tarefa é designado um servidor. No entanto, o objetivo é o mesmo, "diminuir custos e a especialização na prestação dos serviços ou fornecimento de bens" (SEKIDO, 2010, p. 8).

Ocorre, porém, de haver dificuldade na gestão dos contratos de terceirização, no setor público, pela precariedade causada por servidores não qualificados, isso porque estes são alocados em determinada função, não havendo treinamento ou mesmo tempo, devido a quantidade de trabalho que tem de ser realizado. Ou seja, essa precariedade é causada, principalmente, pela "falta de servidores capacitados para gerir e fiscalizar os contratos, responsabilização do Poder Público pelo inadimplemento das empresas contratadas, corrupção etc." (SEKIDO, 2010, p. 8)

Há de se observar que a terceirização é o repasse da prestação de serviço público por particular, conforme entende Silva.

[A terceirização] constitui-se numa das formas pela qual o Estado busca parceria com o setor privado para a realização de suas atividades. Por meio dela, atividades de apoio ou meramente instrumentais à prestação do serviço público são repassadas para empresas privadas especializadas, a fim de que o ente público possa melhor desempenhar suas competências institucionais. (SILVA, 2011, p. 99)

Assim, cabe destacar que se diferencia por atender apenas a uma necessidade pública a ser exercida por particular. Distingue-se da concessão e da permissão por seu objeto, uma vez que na terceirização ocorre apenas a execução material de atividades específicas, e na execução de serviços públicos é fornecida a gestão operacional da atividade. (SILVA, 2011, p. 100)

Conforme o mesmo autor (2011, p. 109-110), os serviços públicos podem se classificar de três formas: a) serviços públicos administrativos: são serviços de reflexo mediato na sociedade e no serviço público final. Em outras palavras, são atividades-meio às quais são indispensáveis para a manutenção e o auxílio da atividade fim. Neste sentido, têm-se o trabalho de vigilância e a manutenção e limpeza. Consoante a este entendimento e a Lei de Licitações, o Decreto 2.271 de 1997 delimita as atividades-meio na Administração Pública $^{7}$; b) serviços públicos sociais: são de

Art. $1^{\circ}$ No âmbito da Administração Pública Federal direta, autárquica e fundacional poderão ser objeto de execução indireta as atividades materiais acessórias, instrumentais ou complementares aos assuntos que constituem área de competência legal do órgão ou entidade.

$\S 1^{\text {o }}$ As atividades de conservação, limpeza, segurança, vigilância, transportes, informática, copeiragem, recepção, reprografia, telecomunicações e manutenção de competência do Estado, mas poderão ser exercidos, em complementariedade, pela iniciativa privada, e estão elencados no art. art. $6^{\circ}$, e no Título VIII da CF/88 educação, saúde e previdência, por exemplo; c) serviços públicos econômicos, comerciais ou industriais: são as situações de competência exclusiva do Estado, no entanto, podem ser exercidos de forma direta ou por entes privados, concessão ou permissão - art. 175 da $\mathrm{CF} / 88$. São atividades que tem fins lucrativos como, por exemplo, os serviços de telefonia e de fornecimento de energia elétrica. Neste tipo de serviço são terceirizados serviços de apoio e considerados de atividade-meio por serem prestados no âmbito da Administração.

Diferente, Medauar (2014, p. 360) entende que o termo serviço público tem dois sentidos, sendo o amplo aquele que engloba qualquer atividade da Administração Pública. Por outro lado, em sentido mais técnico, serviço público é a atividade realizada no âmbito das atribuições da Administração, as quais são necessárias à vida coletiva.

$\mathrm{Na}$ análise de entendimentos da aplicação da nova conjuntura da terceirização à Administração Pública, serão ampliadas as atividades que podem ser terceirizadas, especialmente na Administração Indireta, inclusive as atividades fim. Passa, então, a haver nova possibilidade de contratação para exercer atividades públicas. Antes, concurso público, em regra, e através da Lei de Licitações, excepcionalmente nos casos autorizados. Com a alteração da Lei n. 6.019, a contratação poderá ocorrer de modo mais simples, porém sem perder suas formalidades, através de terceirização.

No entanto, o Conselho Nacional de Procuradores-Gerais do Ministério Público - CNPG (2016) manifesta seu entendimento contrário à terceirização de forma ampla. Assim, entende que fere os ditames constitucionais, em especial direitos fundamentais e a dignidade da pessoa humana, bem como aumenta o risco de miséria, devido ao alto índice de inadimplência das empresas prestadoras de serviços, além da redução de direitos.

Estes preceitos fundamentam a proteção do trabalho, o qual está atrelado ao desenvolvimento do país e da democracia na sociedade e da cidadania nas empresas, pois geram empregos e impedem que as relações de trabalho tornem-se precárias.

prédios, equipamentos e instalações serão, de preferência, objeto de execução indireta.

$\S 2^{\circ}$ Não poderão ser objeto de execução indireta as atividades inerentes às categorias funcionais abrangidas pelo plano de cargos do órgão ou entidade, salvo expressa disposição legal em contrário ou quando se tratar de cargo extinto, total ou parcialmente, no âmbito do quadro geral de pessoal. 
CONSIDERANDO, que o desenvolvimento de um país está essencialmente ligado às oportunidades que ele oferece à população de fazer escolhas e exercer sua cidadania em conformidade com os direitos humanos, entre as quais está a livre escolha de emprego. (CNPG, 2016, p. 1)

O trabalho precário ocorre quando não há condições justas e favoráveis ao exercício da atividade, pois fere a saúde do trabalhador, o que aumenta o índice de acidentes de trabalho, além de favorecer ao desenvolvimento de condição de análoga à escravidão.

CONSIDERANDO, em aspectos pragmáticos, que as estatísticas confirmam que os trabalhadores que prestam serviços por empresas terceirizadas compõe $80 \%$ dos acidentados no trabalho, em vista da precária capacitação para a atividade e o insuficiente (ou ausente) fornecimento de equipamentos de proteção individual (EPI). (CNPG, 2016, p. 2)

Além disso, questiona-se o conceito de empregador e a própria relação de trabalho, dificultando, inclusive, a defesa dos direitos dos trabalhadores por parte do Ministério Público.

CONSIDERANDO que o Tribunal Superior do Trabalho, pela Subseção I de Dissídios individuais, em sua composição plena, especifica que (Acórdão TST-E-ED-RR-2938-13;2010.5.12.0016, SBDI-1, DEJT 26/03/2013), há dois limites ou contrapesos essenciais para se aceitar a terceirização de serviços só ser admissível nas atividades-meio para possibilitar o fornecimento de mão-de-obra especializada por interposta pessoa que significasse um ganho de produtividade e de qualidade técnica na prática dessas atividades de apoio ao de auxílio à atividade essencial de cada empresa e para se organizar o setor econômico e deve ser afastada nas atividades-fim, pois chegar-se-ia, em seu limite lógico, à possibilidade da existência de uma empresa sem empregados, que desenvolvesse todas as suas atividades apenas por meio de trabalhadores terceirizados, desafiando o próprio conceito de empregador. (CNPG, 2016, p. 3)

Corroborando com este entendimento do CNPG, e devido a maior liberdade de contratação mediante a flexibilização da regra constitucional do concurso público para a realização das atividades públicas trará impactos na realização dos concursos públicos, reduzindo-os sobremaneira. Estes demandam custos e tempo para serem realizados. Já a terceirização, traz maior celeridade nesta contratação. No entanto, fraudes podem ocorrer, não apenas para ingressar no serviço público, mas principalmente, na fiscalização do próprio Estado, seus agentes e gestores, uma vez que a contratação, ao ser realizada de modo fraudulento, será camuflado pela mão patrimonialista, para que os interesses destes não se tornem alvo de investigações, sejam elas externas ou internas, através da troca de favores com os funcionários terceirizados controlados pelo patrimonialismo.

Assim, ocorre uma dependência além da subordinação jurídica contratual da relação de emprego, mas também subordinação pessoal, ao haver a ameaça de perda do emprego.

Ao contrário disso, a nova geração que ocupa cargos públicos - a que ingressou a partir da Constituição Federal de 88 -, é marcada por merecimento próprio, uma vez que ingressaram por meio de concurso público, e não por troca de favores. Ocorre então maior autonomia e liberdade para o controle fiscal das atividades Estatais que é realizado por estes agentes. (CAVALCANTE, 2006 p. 68)

A aplicação da terceirização à Administração Pública, nos novos moldes da lei 6.019, abre maior possibilidade de ampliação do interesse pessoal das empresas para que haja a redução da fiscalização da máquina pública. $\mathrm{O}$ princípio da impessoalidade, firmado no art. 37 do texto constitucional, em defesa dos atos da Administração, inclusive nos concursos, seria, também flexibilizado. O interesse de uma categoria terá maior espaço dentro do sistema político atual. Assim, a terceirização poderia exercer o interesse de seus gestores e patrimonialistas, o que na verdade, seria o interesse privado.

Com a terceirização, os funcionários não terão tanta segurança jurídica em seus cargos como tem um concursado. Da mesma forma, não terão capacidade de exercer os atos de fiscalização que compete aos agentes públicos. Os terceirizados tem a brecha de exercerem a troca de favores ou mesmo a ameaça de tomada de seu emprego. Isso, pois o não cumprimento de determinados atos impostos pelo seu empregador, que por sua vez tenha advindo de um agente público, que ainda assim, tenha surgido de um ente privado - patrimonialista e camuflado no sistema político-social -, pode gerar a rescisão de seu vínculo trabalhista. Em contrapartida, o funcionário concursado tem sua segurança em não ser compelido a cumprir determinado favor, pois atingiu seu patamar por seu merecimento próprio.

O concurso público garante maior eficiência dos princípios constitucionais bem como do interesse público. $\mathrm{O}$ agente que age seguindo esta finalidade exerce sua atividade de forma ilibada. A terceirização é de maior valia para governantes que tem interesses adversos ao coletivo e que participam do, ainda existente, patrimonialismo. Este é o interesse desta 
categoria, pois favorece seu interesse privado. Logo, se tem maiores vantagens, inclusive pela facilidade em contratar e exercer cargos públicos, os concursos públicos perderão sua força e importância, podendo futuramente, chegar a sua extinção.

\section{CONSIDERAÇÕES FINAIS}

O fenômeno da terceirização tem produzido profundas transformações no mundo do trabalho e na ordem jurídica, trazendo ao mundo laboral, seja público ou privado, substanciais câmbios e novas formas de mediação que violentam a necessária construção de projetos de vida da massa operaria, ao introduzir na principiologia que norteia a ontologia no campo das relações consideradas pelo direito do trabalho, a permanente preocupação dos atores sociais trabalhistas com as violações dos seus princípios, institutos e regras que caracterizam o jus laboral. A intermediação de mãode-obra por empresas prestadoras de serviços tem substituído cada vez mais os contratos formais por prazo indeterminado por contratos temporários e de frágil apego as boas práticas e as diretrizes da Organização Internacional do Trabalho (OIT) sobre o "trabalho decente", ao que ferir os princípios da continuidade das relações jurídicas laborais e da pessoalidade, cujos desdobramentos minam a segurança econômica e os direitos trabalhistas, ao negar o reconhecimento das novas condições salariais e vantagens decorrentes das convenções e acordos coletivos de trabalho. Trata-se de uma tendência não apenas na esfera do mercado, mas também no âmbito da Administração Pública, marcada atualmente pelo esvaziamento dos quadros de pessoal e pela deficiência do número de servidores públicos nas mais diversas áreas.

O principal objetivo da terceirização na esfera pública, todavia, não parece ser a garantia da eficiência e da qualidade dos serviços oferecidos à população, mas a redução dos gastos estatais, que, em tempos de neoliberalismo, coaduna-se com as estratégias de elevação da produtividade e da lucratividade do capital, uma vez que o enxugamento das responsabilidades sociais do Estado tem possibilitado a abertura de novos nichos de mercado, a exemplo da mercantilização de direitos sociais como a saúde, a educação e até mesmo a previdência social.

Do ponto de vista do trabalho, a terceirização significa perda da vinculação jurídica dos trabalhadores com o Estado, que só pode ocorrer via concurso público, conforme determinação constitucional. Desse modo, há um aumento crescente de terceirizados prestando serviços públicos e ocupando postos de trabalho que deveriam ser ocupados por servidores efetivos, tendo em vista que as demandas sociais às quais atendem são permanentes, e não temporárias; assim como as atividades que realizam são fundamentais à Administração Pública, e não simplesmente meios para efetivar políticas, programas, projetos e serviços sociais.

Ocorre que, por meio de um contrato de prestação de serviços formalmente válido, empregados terceirizados trabalham de forma subordinada, não eventual e com pessoalidade na Administração Pública, executando tarefas típicas e/ou exclusivas de servidores ou de empregados públicos, caracterizando um fornecimento ilegal de mão-de-obra aos entes públicos, isto é, a chamada terceirização ilícita. Esta última, além de violar o princípio do concurso público, acaba por promover o clientelismo político, prejudicando trabalhadores qualificados que não têm a oportunidade de concorrer a uma vaga no serviço público. Ademais, as relações de trabalho dos empregados terceirizados são precárias, uma vez que eles não têm os mesmos direitos reconhecidos aos trabalhadores contratados diretamente pelo Estado e sofrem, ainda, com a instabilidade e a insegurança nas relações de emprego, dada a elevada rotatividade na contratação. Assim, não há sequer como investir na qualificação permanente dos profissionais que atuam nos serviços públicos, o que compromete muitas vezes a continuidade destes e, em última instância, traz graves prejuízos aos usuários de tais serviços.

Portanto, a terceirização ilícita ou ilegal, sobretudo no âmbito da Administração Pública, agride direitos coletivos, na medida em que desrespeita a legislação constitucional e trabalhista, ofendendo direitos e interesses dos trabalhadores. É neste contexto que se tornam relevantes não apenas a atuação do Ministério Público do Trabalho (MPT) - órgão com legitimidade constitucional para a defesa da ordem jurídica trabalhista e dos princípios constitucionais que norteiam a atividade do administrador público nas relações de trabalho -, mas também a articulação dos movimentos sociais, no sentido de lutar pela garantia de direitos historicamente conquistados pela classe trabalhadora, manifestando-se contra as legislações antitrabalhistas que ameaçam a efetivação desses direitos. 


\section{REFERÊNCIAS}

ALEXANDRE, Ricardo; DEUS, João de. Direito Administrativo Esquematizado. Rio de Janeiro/São Paulo: Forense/MÉTODO, 2015. [E-Book]

ALVES, Giovanni. Nova ofensiva do capital, crise do sindicalismo e as perspectivas do trabalho: o Brasil nos anos noventa. In: TEIXEIRA, Francisco José Soares; OLIVEIRA, Manfredo Araújo de. (orgs).

Neoliberalismo e reestruturação produtiva: as novas determinações do mundo do trabalho. $2^{\mathrm{a}}$ ed. São Paulo: Cortez; Fortaleza: Universidade Estadual do Ceará, 1998.

O novo (e precário) mundo do trabalho. Reestruturação produtiva e crise do sindicalismo. São Paulo: Boitempo, 2005.

ANTUNES, Ricardo. Os sentidos do trabalho. Ensaio sobre a afirmação e a negação do trabalho. $3^{\text {a }}$ edição. São Paulo: Boitempo, 2000.

As formas contemporâneas de trabalho e a desconstrução dos direitos sociais. In: SILVA, Maria Ozanira da Silva e; YAZBEK, Maria Carmelita. Políticas públicas de trabalho e renda no Brasil contemporâneo. São Paulo: Cortez; São Luís, MA: FAPEMA, 2006.

AZEVEDO, Fernanda Caldas de. Consultoria empresarial de Serviço Social: expressões da precarização e da terceirização profissional. Serv. Soc. Soc., São Paulo, n. 118, p. 318-338, Junho 2014. Disponível em: <http://www.scielo.br/scielo.php?script=sci_arttext\&pi $\mathrm{d}=$ S0101-66282014000200006\&lng=en\&nrm=iso > .

Acesso em: 23 mar. 2016.

BEHRING, Elaine Rossetti; BOSCHETTI, Ivanete (orgs.). Política Social: fundamentos e história. $4^{\mathrm{a}}$ ed. São Paulo: Cortez, 2008.

BRAMANTE, Ivani Contini. A Aparente Derrota da Súmula 331/TST e a Responsabilidade do poder público na terceirização. Disponível em: <http://www.egov.ufsc.br/portal/sites/default/files/sum ula331-inconst.pdf>. Acesso em: 29 mar. 2016.

BRASIL. Constituição (1988). Constituição da República Federativa do Brasil. Brasília, DF: Senado, 1988.

BRASIL. Presidência da República. Plano Diretor da Reforma do Aparelho do Estado. Disponível em
<http://www.bresserpereira.org.br/Documents/MARE/ PlanoDiretor/planodiretor.pdf $>$. Acesso em 25 de ago. 2019.

\footnotetext{
. Tribunal Superior do Trabalho (TST). Súmula $\mathbf{n}^{\circ}$ 331. Redação determinada pela Resolução $n^{\circ} 174$, de 24/5/2011.
}

BRASIL. Câmara dos Deputados. Projeto de Lei $\mathbf{n}^{\mathbf{0}}$ 4330/04. Dispõe sobre contrato de prestação de serviço a terceiros e as relações de trabalho dele decorrentes. Disponível em: <http://www.camara.gov.br/proposicoesWeb/prop_mo strarintegra;jsessionid=F47EAD76876079E21FCC4D 39E42E4775.proposicoesWeb2?codteor $=1325350 \&$ fil ename $=$ Tramitacao-PL+4330/2004 $>$. Acesso em: 20 mar. 2016.

Constituição da República Federativa do Brasil de 1988. Diário Oficial da União, Brasília. Disponível em: <__ Decreto-lei n.200/67, de 25 de fevereiro de 1967. Dispõe sobre a organização da Administração Federal, estabelece diretrizes para a Reforma Administrativa e dá outras providências. Diário Oficial da União, Brasilia. Disponível em: <http://www.planalto.gov.br/ccivil_03/decretolei/Del0200.htm>. Acesso em: 12 set. 2016.

Justiça em Números 2015: ano-base 2014. Conselho Nacional de Justiça - Brasília: CNJ, 2015. Disponível em: <http://www.cnj.jus.br/programas-eacoes/pj-justica-em-numeros>. Acesso em: 2 out. 2016.

\section{Ofício n. 240/2016-PRES. Conselho} Nacional De Procuradores-Gerais do Ministério Público dos Estados e da União - Natal: CNPG 2016. Disponível em:

http://www.senado.leg.br/atividade/rotinas/materia/get PDF.asp?t=201841\&tp=1>. Acesso em: $04 \mathrm{dez} 2016$.

. Supremo Tribunal Federal. (Voto Ministro Celso de Melo ADPF n ${ }^{\circ}$ 324/DF e RE 958.252). Acesso em: 20 set. 2018.

Tribunal Superior do Trabalho. Súmula ${ }^{\circ}$ 331. Súmulas. Res. 174/2011. DEJT 27, 30 e 31 mai. 2011. Disponível em: 〈www.tst.jus.br〉. Acesso em: 20 mar 2016.

http://www.planalto.gov.br/ccivil_03/constituicao/cons tituicaocompilado.htm>. Acesso em: 20 mar. 2016.

BOURDIEU, Pierre. O Poder Simbólico. Rio de 
Janeiro: Bertrand Brasil, 1989.

CARELLI, Rodrigo de Lacerda. Terceirização e direitos trabalhistas no Brasil. In: FRANCO, Tânia; DRUCK, Graça (orgs.). A perda da razão social do trabalho: terceirização e precarização. São Paulo: Boitempo, 2007.

CARVALHO, Matheus. Manual de Direito Administrativo. 6 ed. Salvador: JusPODIVM, 2019.

CARVAlHO FILHO, José dos Santos. Manual de Direito Administrativo. $19^{\mathrm{a}}$ ed. Rio de Janeiro: Lumen Juris, 2008.

CASTEL, Robert. A Metamorfose da Questão Social: uma crônica do salário. RJ: Vozes, 1998.

CAVAIGNAC, M. D. Relações de trabalho e relações no trabalho na lógica capitalista contemporânea: um olhar sobre atendentes do call center de uma empresa de telecomunicações. Tese (Doutorado em Sociologia)Programa de Pós-Graduação em Sociologia, Universidade Federal do Ceará. Fortaleza, 2010.

CAVALCANTE, Denise Lucena. Dos tributos para as Finanças Públicas: Ampliação do Foco. Revista do curso de Mestrado em Direito da UFC. Disponível em:

<http://www.repositorio.ufc.br/bitstream/riufc/12341/1 /2006_art_dlcavalcante.pdf>. Acesso em: 29 Mar. 2016.

CASSAR, Vólia Bomfim. Direito do Trabalho. $9^{\text {a }} \mathrm{Ed}$. Rio de Janeiro: Forense; São Paulo: Método, 2014. Capítulo 15. Terceirização (p. 479-514).

CHESNAIS, François. A mundialização do capital. Tradução Silvana Finzi Foá. São Paulo: Xamã, 1996.

CRUZ, Luiz Guilherme Ribeiro da. A Terceirização Trabalhista no brasil: aspectos gerais de uma flexibilização sem limite. Revista do Centro Acadêmico Afonso Pena - CAAP - $1^{\circ}$ semestre, 2009. p. 319-343. Disponível em <http://www2.direito.ufmg.br/revistadocaap/index.php /revista/article/viewFile/32/31>. Acesso em: 08 out. 2016.

DELGADO, Maurício Godinho. Curso de Direito do Trabalho. $3^{\mathrm{a}}$ ed. São Paulo: LTr, 2004. Capítulo XIII. Terceirização trabalhista (p. 428-470).

DIAS, Sabrina de Oliveira Moura. Trabalhadores terceirizados e luta sindical. Sociologia, Porto
Alegre, v. $\quad 17$, n. $\quad 38$, p. $\quad 314-$ 324, Abril 2015. Disponível em: $<$ http://www.scielo.br/scielo.php?script=sci_arttext\&pi $\mathrm{d}=\mathrm{S} 1517-45222015000100314 \& \operatorname{lng}=\mathrm{en} \& \mathrm{nrm}=\mathrm{iso}>$.

Acesso em: 23 Mar. 2016.

FAORO, Raymundo. A aventura liberal numa ordem patrimonialista. Revista USP - 1993. N 17. P. 14-29. Disponível em: <http://www.revistas.usp.br/revusp/article/view/25950/ 27681>. Acesso em: 2 set. 2016.

FARIA, Leonardo Rocha de; SILVA, Maria de Fátima da. Aspectos Da Terceirização E A Responsabilidade Trabalhista: análise da Súmula 331, do TST e da Lei 11.442/07. Revista CEPPG da CESUC, ano XV, n. 26, 1. sem. 2012. Disponível em: <http://www.portalcatalao.com/painel_clientes/cesuc/p ainel/arquivos/upload/temp/769263288c34526bf968ac 4c6cff9e80.pdf>. Acesso em: 23 mar. 2016.

GASPARINI, Diógenes. Direito Administrativo. 8 ed. São Paulo: Saraiva, 2003.

HOLANDA, Sérgio Buarque de. Raízes do Brasil. São Paulo: Companhia das Letras, 2016. [E-Book]

IMHOFF, Márcia Moraes. MORTARI, Aline Perico. Terceirização, vantagens e desvantagens para as empresas. Revista Eletrônica de Contabilidade do Curso de Ciências Contábeis da Universidade Federal de Santa Maria, Edição Especial - julho de $2015 . \quad$ Disponível em: <http://tupi.fisica.ufmg.br/ michel/docs/Artigos_e_tex tos/Gestao/terceirizacao_vantagens_desvantagens.pdf $>$ . Acesso em: 28 out. 2016.

JORGE NETO, Francisco Ferreira; CAVALCANTE, Jouberto de Quadros Pessoa. Direito do Trabalho. $7^{\mathrm{a}}$ ed. São Paulo: Atlas, 2013. Capítulo XII. Aspectos da terceirização (p. 434-465).

Lei da terceirização é a maior derrota popular desde o golpe de 64. Disponível em: $\langle$ http://www.cartacapital.com.br/economia $>$. Acesso em: maio/2015.

LOURENÇO, Edvânia Ângela de Souza. Terceirização: a derruição de direitos e a destruição da saúde dos trabalhadores. Serviço Social, São Paulo, n. 123, p. 447-475, set. 2015. Disponível em $<$ http://www.scielo.br/scielo.php?script=sci_arttext\&pi $\mathrm{d}=$ S0101-66282015000300447\&lng=pt\&nrm=iso> .

Acesso em: 23 mar. 2016

MEDAUAR, Odete. Direito Administrativo 
Moderno. 18 ed. revisada e atualizada. São Paulo: Editora Revista dos Tribunais, 2014.

MEIRELLES, Hely Lopes. Direito administrativo brasileiro. 42 ed. São Paulo: Malheiros, 2016.

MÉSZÁROS, István. Para além do capital. Tradução Paulo César Castanheira e Sérgio Lessa. São Paulo: Boitempo, 2002.

SARAIVA, Renato; SOUTO, Rafael Tonassi. Direito do Trabalho. $16^{\mathrm{a}}$ ed. Rio de Janeiro: Forense; São Paulo: Método, 2014 (Concursos Públicos). Capítulo 9. Direito público nas relações de trabalho (p. 335-349).

SANTORO, Bernardo. Em Defesa da Terceirização. $2015 . \quad$ Disponível em: $<$ http://www.institutoliberal.org.br/blog/em-defesa-daterceirizacao/>. Acesso em: 01 jun. 2016

SEKIDO, Amelia Midori Yamane. Terceirização na Administração Pública: A gestão e a fiscalização dos contratos. 2010. 61 f. Monografia (Especialização em Auditoria Governamental) - Universidade Gama Filho, Brasília, 2010. Disponível em: <https://www2.mppa.mp.br/sistemas/gcsubsites/upload /56/Artigo\%20-

$\% 20$ Contrato $\% 20 \mathrm{de} \% 20 \mathrm{Gest} \% \mathrm{C} 3 \% 83 \% \mathrm{C} 2 \%$ A3o.pdf >. Acesso em: 30 mar. 2016.

SILVA, Kênia Lara et al. Promoção da saúde no setor suplementar: terceirização, microrregulação e implicações no cuidado. Revista Brasileira de Enfermagem, Brasília, v. 68, n. 3, p. 482489, Junho 2015.2 Disponível em: <http://www.scielo.br/scielo.php?script=sci_arttext\&pi $\mathrm{d}=$ S0034-71672015000300482\&lng=en\&nrm=iso >.

Acesso em: 23 Mar. 2016.

SILVA, Patrícia Pinheiro. Terceirização nos Serviços Públicos. Revista TST, Brasília vol. 77, n. 1, jan./mar. 2011. Disponível em: <http://www.tst.jus.br/documents/1295387/1313002/5. +Terceiriza\%C3\%A7\%C3\%A3o+nos+servi\%C3\%A7 $\mathrm{os}+\mathrm{p} \% \mathrm{C} 3 \%$ BAblicos? version $=1.0>$. Acesso em: 30 mar. 2016.
SILVA, Ricardo Margonari. Liberalismo e a Terceirização no setor público brasileiro: um estudo acerca da terceirização na Universidade Federal de Uberlândia. Marx 2014: Seminário Nacional de Teoria Marxista - Uberlândia, 2014, p. 5-7. Disponível em: <http://tupi.fisica.ufmg.br/ michel/docs/Artigos_e_tex tos/Gestao/terceirizacao_vantagens_desvantagens.pdf> . Acesso em: 28 de out. de 2016.

SOUZA, Eduardo Xavier. O Ministério Público do Trabalho e a terceirização ilícita no âmbito da administração pública. Disponível em http://jus.com.br/artigos. Acesso em março/2015.

TELLES, Vera da Silva. Direitos sociais: afinal do que se trata? Belo Horizonte: Ed. UFMG, 1999.

Terceirização é discutida em Congresso Brasileiro de Direito e Saúde. Disponível em http://www.prt7.mpt.gov.br. Acesso em março/2015.

THÉBAUD-MONY, Annie; DRUCK, Graça. Terceirização: a erosão dos direitos dos trabalhadores na França e no Brasil. In: DRUCK, Graça; FRANCO, Tânia; (orgs.). A perda da razão social do trabalho: terceirização e precarização. São Paulo: Boitempo, 2007.

VARGAS, Luiz Alberto de; SILVEIRA, Almir Goulart da. A Terceirização e o Enunciado 331 do TST. Breves Considerações. Direito em Revista, Amatra IV, Porto Alegre, $1994 . \quad$ Disponível em: <http://www.lavargas.com.br/terceira.html>. Acesso em: 02 jun. 2016.

VIANA, Márcio Túlio; DELGADO, Gabriela Neves; AMORIM, Helder Santos. Terceirização - Aspectos Gerais. A Última Decisão do STF e a Súmula 331 do TST.

WOLFE, Luciana Silva Ceolin. A Caracterização da Terceirização e o Direito do Trabalho: Súmula 331 TST. Disponível em: <http://www.unibrasil.com.br/arquivos/direito/20092/1 uciana-silva-ceolin-wolfe.pdf >. Acesso em: 02 jun. 2016. 